\title{
Assessment of diversity and genetic relationships of Neonectria ditissima: the causal agent of fruit tree canker
}

\author{
Marjan Ghasemkhani ${ }^{1 *}$ (D), Larisa Garkava-Gustavsson ${ }^{1}$, Erland Liljeroth² ${ }^{2}$ and Hilde Nybom³
}

\begin{abstract}
Background: Neonectria ditissima is one of the most important fungal pathogens of apple trees, where it causes fruit tree canker. Information about the amount and partitioning of genetic variation of this fungus could be helpful for improving orchard management strategies and for breeding apple cultivars with high levels of genetically determined resistance. In this study single-spore Neonectria isolates originating from both the same and from different perithecia, apple cultivars and apple orchards in Sweden and Belgium, were evaluated for AFLP- and SSR-based genetic similarity and for mating system.

Results: Seven SSR loci produced a total of 31 alleles with an average of 4 alleles per locus, while 11 AFLP primer combinations produced an average of 35 fragments per primer combination and $71 \%$ polymorphic fragments. An AFLP-based analysis of molecular variance (AMOVA) revealed that $89 \%$ of the variation was found within orchards and $11 \%$ between orchards. Genetic similarity among the studied isolates was illustrated with a principal coordinate analyseis (PCOA) and a dendrogram. AFLP-based Jaccard's similarity coefficients were the highest when single-ascospore isolates obtained from the same perithecium were compared, medium-high for isolates from different perithecia on the same tree, and lowest when isolates from different trees were compared.
\end{abstract}

Conclusions: Based on the results of PCOA and AMOVA analysis, isolates from the same or geographically close orchards did not group together. Since AFLP profiles differed also when single-ascospore isolates from the same perithecium were compared, the mating system of $\mathrm{N}$. ditissima is most likely heterothallic.

Keywords: AFLP, Apple canker, Genetic variability, Heterothallism, Mating system, SSR

\section{Background}

The haploid fungus Neonectria ditissima (Tul. \& C. Tul.) Samuels \& Rossman, previously known as Neonectria galligena (Bres.) Rossman \& Samuels, causes cankers on a wide range of trees and shrubs including apple (Malus) and pear (Pyrus). This pathogen can damage the woody tissue of infected trees substantially, and render fruit production unprofitable in certain areas [5]. Apple canker is mainly associated with mild and wet conditions, and climate therefore has an important impact on the geographic distribution of the pathogen [6]. This pathogen produces both conidia and ascospores under favorable conditions over prolonged periods [20,33]. The

\footnotetext{
*Correspondence: marjan.ghasemkhani@slu.se

'Department of Plant Breeding, Swedish University of Agricultural Sciences,

Box 101, 23053 Alnarp, Sweden

Full list of author information is available at the end of the article
}

spores usually enter the trees through natural and artificial wound sites e.g., pruning wounds, leaf scars, fruit scars due to chemical thinning or natural abscission, twig stubs, in the crotches of limbs, and even through lesions caused by apple scab. The spores can also be dispersed within and between orchards with infected equipment used by growers [20]. Since the pathogen can cause systemic infections that spread inside the plant, the use of infected rootstocks can probably lead to canker symptoms also in the grafted part (i.e. the proper cultivar) of young apple trees.

In spite of the economic impacts of this pathogen, very little is known about the genetics of the causal agent. Most studies of Neonectria have focused on analyses of material from North America. In a study of Mahoney et al. [17], Restriction Fragment Length Polymorphism (RFLP) of ribosomal, mitochondrial, and anonymous nuclear DNA was used to determine the origin of $N$. 
coccinea var. faginata in North America, and also to estimate haplotype and nucleotide diversity in this species as well as in $N$. ditissima. Plante et al. [25] investigated genetic diversity of $N$. ditissima and $N$. coccinea var. faginata using Random Amplified Polymorphic DNA (RAPD) and ribosomal DNA polymorphisms, and found that diversity of $N$. ditissima on various hardwood hosts in North America was higher than that of $N$. faginata (Nectria coccinea var. faginata). Based on a combined analysis of elongation factor 1-alpha (EF1- $\alpha)$, RNA polymerase II second largest subunit (RPB2), and $\beta$-tubulin gene regions, Castlebury et al. [4] report that $N$. ditissima appears to consist of two major groups; one with primarily North American isolates, and another with European isolates from Fagus, Malus and Salix.

Fungi can be self-fertile and undergo sexual reproduction (haploid selfing) on a single colony or be self-sterile and require two colonies of different mating types for sexual reproduction (out-crossing) [2]. However, many fungi can revert to haploid selfing if a suitable partner is not available.

Studies of fungal population biology can assist in understanding the evolution of disease in agriculture and how it is affected by, e.g., the life cycle of the pathogen [26]. Population genetic analyses can also provide information about the amount of sexual recombination in fungal populations [32]. Sexual pathogen populations can produce new combinations of alleles including fungicide resistance alleles, which allow the pathogen to rapidly adapt to changes in the environment [21]. Analysis of sibling ascospore offspring can be used to more closely define the nature of mating systems [7]. Out-crossing was thus concluded when RAPD- and AFLP-markers detected genetic variation among sibling single-ascospore progeny from apothecia of Cladonia xoerkeana, C. galindezii, and C. portentosa [27]. However, previously collected data for $N$. ditissima are conflicting; based on the morphology of macroconidia and ascospores, El-Gholl et al. [9] reported this species to be homothallic while out-crossing was reported in an older study of ascospore morphology [14].

\section{Methods}

\section{Fungal isolates}

Ascospore samples were collected from vegetatively propagated apple cultivars grown in seven different apple orchards in southern Sweden and from one orchard in Belgium (Fig. 1 and Table 1). In each orchard, 2-10 trees, located in different places in the orchard, with visible canker lesions were chosen, and pieces of bark and wood bearing perithecia were collected. Individual perithecia were surface-sterilized by immersion for $30 \mathrm{~s}$ in $50 \%$ ethanol and for $30 \mathrm{~s}$ in $1.5 \%$ sodium hypochloride, and then washed in sterile distilled water.
Each perithecium was crushed in $100 \mu \mathrm{l}$ of sterile distilled water. About $50 \mu \mathrm{l}$ of the spore suspension was plated on agar (Difco) plates containing tetracycline (100 ppm) and incubated at $21{ }^{\circ} \mathrm{C}$. One day later, $1-3$ germinated ascospores were recovered individually using a tiny needle under a stereo-microscope, and transferred onto fresh $2 \%$ malt extract agar (MEA, Merck) plates and left to grow for 14-18 days to produce singleascospore cultures [1]. Correct species determination was ascertained by observation of colony morphology and by PCR amplification of DNA samples using species-specific primers previously developed for $N$. ditissima [13].

\section{DNA extraction}

For DNA extraction of the isolates of $N$. ditissima, an agar plug of each fungal culture was transferred into liquid medium, malt extract/glucose/peptone (MGP, $20 \mathrm{~g}$ malt extract, $20 \mathrm{~g}$ glucose and $1 \mathrm{~g}$ peptone in $1 \mathrm{~L}$ water at $\mathrm{pH}$ 5.5) [28], and grown at room temperature on a shaker platform for 10 days. The mycelium was harvested by filtration through Whatman No. 1 filter paper, washed two times with distilled water, freeze-dried and stored at $-20{ }^{\circ} \mathrm{C}$ until processing. DNA was extracted with DNeasy Plant Mini Kit (Qiagen GmbH, Hilden, Germany) according to manufacturer's instructions. DNA quantification was performed using electrophoresis in $1.5 \%$ agarose gel containing ethidium bromide and visualized by UV fluorescence, and concentrations and purity $(260 / 280 \mathrm{~nm}>1.8)$ were estimated using a ND-1000 spectrophotometer (NanoDrop, Wilmington, USA).

\section{Amplification with SSR markers}

Seven primer pairs, previously developed from isolates of $N$. ditissima sampled on black birch, Betula nigra [19], were used for SSR analysis. Polymerase chain reaction (PCR) was performed in a total volume of $25 \mu \mathrm{L}$ in $2.5 \mu \mathrm{l}$ of $10 \mathrm{X}$ PCR buffer, $0.2 \mathrm{mM}$ dNTP mix, $0.5 \mu \mathrm{M}$ of each primer, $1.5 \mathrm{mM} \mathrm{MgCl}_{2}, 1$ Unit of Taq DNA polymerase (Thermo Scientific, San Jose, USA) and $10 \mathrm{ng}$ genomic DNA. Amplifications were performed in a S1000 thermal cycler (BIO-RAD, San Francisco, USA) with the following cycling profile: $94{ }^{\circ} \mathrm{C}$ for $5 \mathrm{~min}, 10$ cycles of $94{ }^{\circ} \mathrm{C}$ for $30 \mathrm{~s}, 58{ }^{\circ} \mathrm{C}$ for $45 \mathrm{~s}$, and $72{ }^{\circ} \mathrm{C}$ for $45 \mathrm{~s}$, followed by 30 cycles of $94{ }^{\circ} \mathrm{C}$ for $30 \mathrm{~s}, 53{ }^{\circ} \mathrm{C}$ for $45 \mathrm{~s}$, and $72{ }^{\circ} \mathrm{C}$ for $45 \mathrm{~s}$, a final extension step for $7 \mathrm{~min}$ at $72{ }^{\circ} \mathrm{C}$.

\section{Amplification with AFLP markers}

AFLP analysis of DNA was carried out with the AFLP Microbial Fingerprinting kit (Applied Biosystems, Foster City, CA, USA) according to the recommendations of the manufacturer. Restriction-ligation reaction and preselective amplification of the AFLP procedure were carried out 


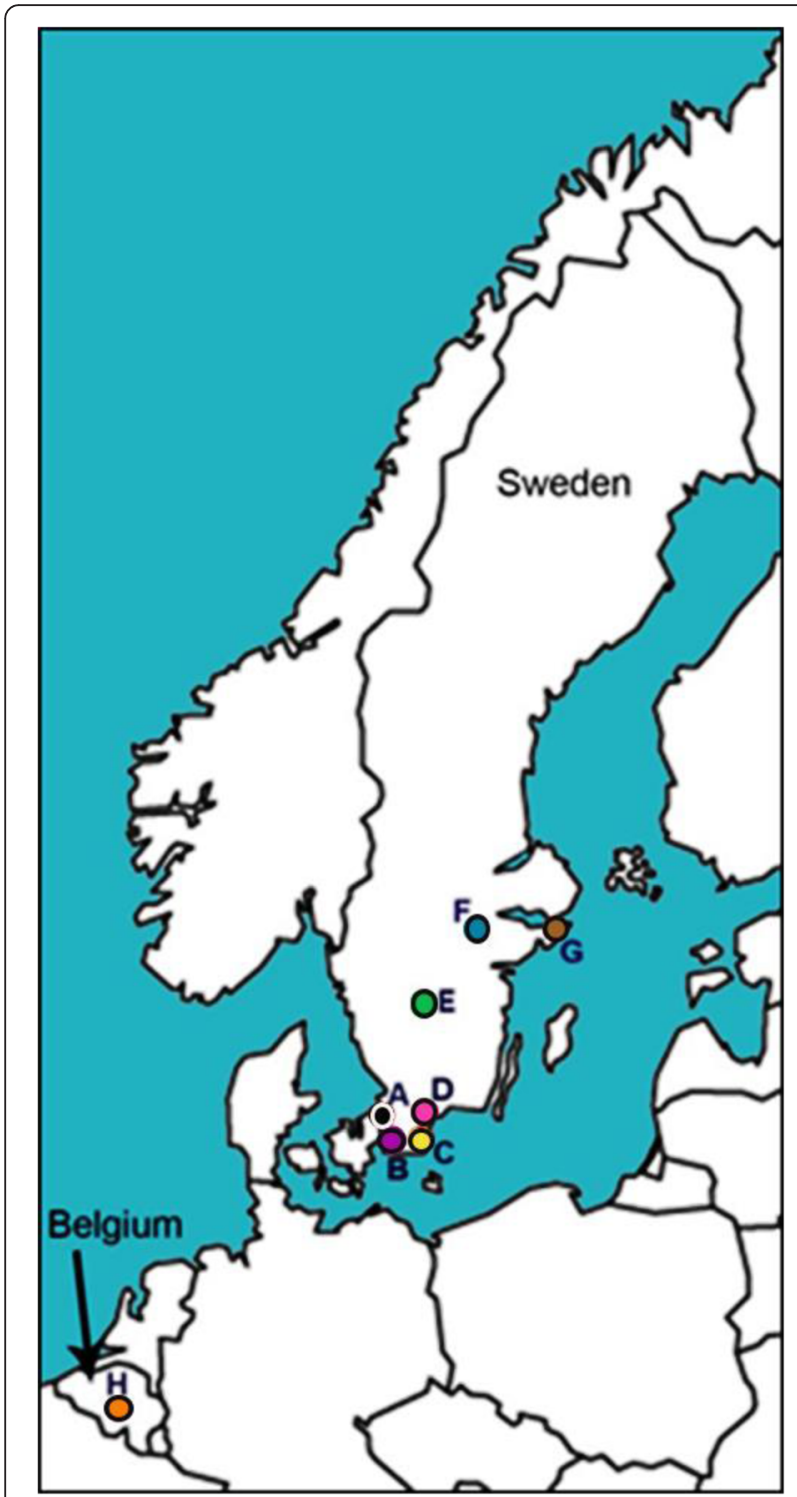

Fig. 1 Map showing origin of isolates in Sweden and Belgium, A (black circle): Jonstorp, B (purple circle): Bjärred, C (yellow circle): Kivik, D (pink circle): Balsgård, E (green circle): Jönköping, F (blue circle): Julita, G (brown circle): Stockholm, H (orange circle): Gembloux

using the AFLP Ligation and Preselective Amplification Module of the Microbial Fingerprinting kit. Briefly, in the restriction-ligation reactions $10 \mathrm{ng}$ of genomic DNA was simultaneously digested with EcoRI and MseI endonucleases (New England Biolabs, Beverly, Mass., USA) and ligated to EcoRI and MseI adaptors in a final volume of $11 \mu \mathrm{l}$ containing 10X T4 DNA ligase buffer with ATP, MseI, EcoRI, T4 DNA ligase, BSA (all: New England Biolabs, Mass., USA), $0.5 \mathrm{M} \mathrm{NaCl}$, and EcoRI-adaptors and MseI-adaptors (Applied Biosystems). Restriction-ligation reactions were carried out for $2 \mathrm{~h}$ at $37{ }^{\circ} \mathrm{C}$ in a Bio-Rad S1000 thermal cycler. After dilution of DNA with $\mathrm{TE}_{0.1}$ buffer (20 mM Tris-HCl, $0.1 \mathrm{mM}$ EDTA, pH 8.0), for the preselective amplification, $4 \mu \mathrm{l}$ diluted DNA was amplified with the EcoRI and MseI core primer sequences (Applied Biosystems) in a final volume of $20 \mu$ l. Selective amplification was performed with 11 primer combinations of fluorescently labelled primers binding to the EcoRI-adaptor and unlabeled primers binding to the MseI-adaptor: $\mathrm{E}+\mathrm{AA} /$ $\mathrm{M}+\mathrm{CA}, \mathrm{E}+\mathrm{A} / \mathrm{M}+\mathrm{CT}, \mathrm{E}+\mathrm{T} / \mathrm{M}+\mathrm{CT}, \mathrm{E}+\mathrm{AC} / \mathrm{M}+\mathrm{CT}, \mathrm{E}+\mathrm{AC} / \mathrm{M}$ $+\mathrm{CA}, \mathrm{E}+\mathrm{AG} / \mathrm{M}+\mathrm{CT}, \mathrm{E}+\mathrm{AT} / \mathrm{M}+\mathrm{CT}, \mathrm{E}+\mathrm{AA} / \mathrm{M}+\mathrm{CT}, \mathrm{E}+\mathrm{AG} /$ $\mathrm{M}+\mathrm{CG}, \mathrm{E}+\mathrm{AC} / \mathrm{M}+\mathrm{CC}, \mathrm{E}+\mathrm{AC} / \mathrm{M}+\mathrm{CG}$, by using $3 \mu \mathrm{l}$ of the diluted preselective amplification reaction mixture in a final volume of $20 \mu \mathrm{l}$. All PCR amplifications were carried out in a BioRad S1000 thermal cycler.

In order to check the reproducibility of AFLP amplification, 5-8 randomly selected samples were added as technical replicates to each 96 -well plate before running the PCR.

\section{Fragment detection and analysis}

The reaction products were mixed with $0.1 \mathrm{x}$ TE buffer and a $\mathrm{ROX}^{\mathrm{Tm}}$ dye-labeled size standard with fragments in the range 58-362 bp for SSR and 50-500 bp for AFLP markers and electrophoresed on an ABI 3130xl DNA analyzer (Applied Biosystems) using a $36 \mathrm{~cm}$ capillary array and POP $-7^{\mathrm{mu}}$ polymer. Trace files were analyzed with GeneMarker ${ }^{\circ}$ software (Version 1.85, SoftGenetics LLC, State College, PA, USA). AFLP markers producing weak or ambiguous signals, relative fluorescence unit $($ RFU) $>100$, were not considered.

\section{Data analysis}

Distinct and well-resolved SSR and AFLP fragments were scored using the GeneMarker ${ }^{\circ}$ program, and converted to binary data (one separate file for SSR data and one for AFLP data) based on the presence or absence of the discriminatory bands ( 1 for presence and 0 for absence). Genetic diversity was evaluated using the program POPGENE v 1.32 [36], and the following parameters: number of alleles (NA, for SSR), number of polymorphic loci (NPL, for AFLP), percentage of polymorphic loci (PPL, for AFLP), Nei's gene diversity $(\mathrm{H}$, both marker types), and Shannon's information index (I, both marker types). Pair-wise comparisons of single-ascospore isolates were conducted using Jaccard's similarity coefficient (SJ), according to the formula $S J=\left(N_{a b}\right) /\left(N_{a}+N_{b}-N_{a b}\right)$, where $\mathrm{N}_{\mathrm{ab}}$ is number of shared bands; $\mathrm{N}_{\mathrm{a}}$ and $\mathrm{N}_{\mathrm{b}}$ are number of bands in isolates a and b, respectively [34]. Genetic relationships among the studied single-ascospore isolates were also assessed by two multivariate principal coordinate analyses (PCoA) performed with NTSYS 2.02 (Applied Biostatistics, Setauket, NY, USA) for SSR and AFLP data, respectively. A dendrogram was constructed by binary band matching using the unweighted pairwise group method with arithmetic mean (UPGMA) with NTSYS 2.02 [30] for single ascospore isolates sampled 
Table 1 Geographic origin of the 44 isolates of N. ditissima used in this study. Number 1-38 were isolated in 2013 and the remainder in 2014

\begin{tabular}{|c|c|c|c|}
\hline Number & CBS & Apple cultivar & Origin \\
\hline Isolate 1 & 139272 & Aroma & Jonstorp, Sweden (N 56 $13^{\prime}$, E 1240') \\
\hline Isolate 2 & 139273 & Ingrid Marie & Jonstorp, Sweden \\
\hline Isolate 3 & 139271 & Rubinstar & Jonstorp, Sweden \\
\hline Isolate 4 & 139269 & Åkerö & Julita, Sweden (N 59 $11^{\prime}$, E $\left.16^{\circ} 1^{\prime}\right)$ \\
\hline Isolate 5 & 139270 & Norrstack & Julita, Sweden \\
\hline Isolate 6 & 139388 & Oranie & 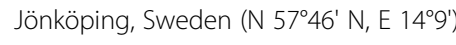 \\
\hline Isolate 7 & 139268 & James Grieve & Jönköping, Sweden \\
\hline Isolate 8 & 139390 & Discovery & 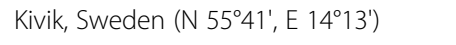 \\
\hline Isolate 9 & 139389 & Ingrid Marie & Kivik, Sweden \\
\hline Isolate 10 & 139265 & John Standish & Balsgård, Sweden (N 566', E 149') \\
\hline Isolate 11 & 139267 & Brite Spur & Balsgård, Sweden \\
\hline Isolate 12 & 139327 & Pigeon & Balsgård, Sweden \\
\hline Isolate 13 & 139266 & Mclntosh & Balsgård, Sweden \\
\hline Isolate 14 & 139255 & Tompkin's King & Balsgård, Sweden \\
\hline Isolate 15- RPIA1 & 139260 & Red Delicious & Balsgård, Sweden \\
\hline Isolate 16- RP2A1 & -—-一-— & Red Delicious & Balsgård, Sweden \\
\hline Isolate 17-RP3A1 & - - - - & Red Delicious & Balsgård, Sweden \\
\hline Isolate 18- RP3A2 & -——-— & Red Delicious & Balsgård, Sweden \\
\hline Isolate 19- RP3A3 & -二-二-— & Red Delicious & Balsgård, Sweden \\
\hline Isolate 20 & 139262 & Beacon & Balsgård, Sweden \\
\hline Isolate 21- HP1A1 & 139263 & Holsteiner Cox & Balsgård, Sweden \\
\hline Isolate 22- HP1A2 & -——-— & Holsteiner Cox & Balsgård, Sweden \\
\hline Isolate 23- HP1A3 & - - & Holsteiner Cox & Balsgård, Sweden \\
\hline Isolate 24- HP3A1 & -——-— & Holsteiner Cox & Balsgård, Sweden \\
\hline Isolate 25- HP3A2 & -二-二- & Holsteiner Cox & Balsgård, Sweden \\
\hline Isolate 26- HP2A1 & -——-— & Holsteiner Cox & Balsgård, Sweden \\
\hline Isolate 27- HP2A2 & -二-二-— & Holsteiner Cox & Balsgård, Sweden \\
\hline Isolate 28- HP2A3 & -二-二-二- & Holsteiner Cox & Balsgård, Sweden \\
\hline Isolate 29 & 139264 & Freiherr von Berlepsch & Balsgård, Sweden \\
\hline Isolate 30- GP1A1 & 139261 & Gravensteiner & Balsgård, Sweden \\
\hline Isolate 31- GP1A2 & -二-—- & Gravensteiner & Balsgård, Sweden \\
\hline Isolate 32- GP1A3 & -———- & Gravensteiner & Balsgård, Sweden \\
\hline Isolate 33- GP2A1 & -——-— & Gravensteiner & Balsgård, Sweden \\
\hline Isolate 34- GP2A2 & -—-ー-—- & Gravensteiner & Balsgård, Sweden \\
\hline Isolate 35- GP2A3 & -二-二-二- & Gravensteiner & Balsgård, Sweden \\
\hline Isolate 36 & 139275 & Gloster & Bjärred, Sweden (N 554', E 131') \\
\hline Isolate 37 & 139274 & Ingrid Marie & Bjärred, Sweden \\
\hline Isolate 38 & 139503 & Elise & Bjärred, Sweden \\
\hline Isolate 39 & 139259 & Discovery & Gembloux, Belgium N 5434', E 442') \\
\hline Isolate 40 & 139257 & Api Etoile & Gembloux, Belgium \\
\hline Isolate 41 & 139256 & Baron & Gembloux, Belgium \\
\hline
\end{tabular}


Table 1 Geographic origin of the 44 isolates of $N$. ditissima used in this study. Number 1-38 were isolated in 2013 and the remainder in 2014 (Continued)

\begin{tabular}{llll}
\hline Isolate 42 & 139258 & Reinette & Gembloux, Belgium \\
Isolate 43 & 139277 & Eva-Lotta & Stockholm, Sweden (N 59¹9', E 184') \\
Isolate 44 & 139276 & Södermanlandsäpple & Stockholm, Sweden \\
\hline
\end{tabular}

Isolator: Marjan Ghasemkhani

CBS-KNAW Fungal Biodiversity Center, Utrecht, The Netherlands

R: Red Delicious, G: Gravensteiner, H: Holsteiner Cox, P1-3: different perithecia on the same tree, A1-3: different single-ascospore isolates from the same perithecium

from perithecia on three trees at Balsgård and investigated with AFLP. A cophenetic correlation coefficient was calculated using a Mantel test [18] in order to check the goodness-of-fit of the cluster analysis with the matrix on which it was based. A Mantel test was also performed to investigate possible correlation between two genetic distance matrices based on SSR and AFLP markers using NTSYS 2.02. An analysis of molecular variation (AMOVA) was calculated for partitioning of AFLP marker variation between and within orchards, using Arlequin $3.11[10]$.

\section{Results and discussion}

\section{Evaluation of primers used}

Seven different SSR primer pairs were used (Table 2), with number of alleles varying from 2 to 7 per locus. Since all single-ascospore isolates collected from a single tree produced identical profiles, only one isolate for each tree (a total of 28) was used in subsequent analyses. Shannon's information index varied from 0.15 for primer NdGGT39 to 0.51 for primer NdGGT3. NdGGT39 also yielded the highest Nei's gene diversity (0.69) while NdGGT23 produced the lowest (0.13). The average gene diversity for the seven primer pairs was 0.28 . When evaluated on $N$. ditissima isolates collected from a single black birch population, gene diversity obtained with the same seven primer pairs was considerably higher, ranging from 0.11 to 0.86 , and with an average of 0.48 [19]. These results suggest that the fungal populations occurring on apple were less variable than the single population occurring on black birch.

Eleven different AFLP primer combinations (Table 3) were used in this study to generate AFLP profiles for 44 isolates. A total of 391 fragments (ranging from 50 to $500 \mathrm{bp}$ ) were identified, of which 272 were polymorphic with reliable and clear reading. The lowest number of fragments was detected for the combination $\mathrm{E}+\mathrm{AC} / \mathrm{M}$ $+\mathrm{CG}$ and the highest for the combination $\mathrm{E}+\mathrm{T} / \mathrm{M}+\mathrm{CT}$, with 21 and 58 fragments, respectively. The percentage of polymorphism ranged from $55 \%$ (in the combination $\mathrm{E}+\mathrm{A} / \mathrm{M}+\mathrm{CT}$ ) to $96 \%$ (in the combination $\mathrm{E}+\mathrm{AC} / \mathrm{M}+\mathrm{CC}$ ). The combination $\mathrm{E}+\mathrm{AC} / \mathrm{M}+\mathrm{CC}$ also produced the highest values for Nei's gene diversity and Shannon's information index while the combination $\mathrm{E}+\mathrm{AA} / \mathrm{M}+\mathrm{CT}$ produced the lowest values. Evaluation of the technical replicates, which were included in each 96-well plate, demonstrated high reproducibility of produced band patterns (Fig. 2).

Overall, SSR markers showed a higher level of polymorphism (100 \%) than the AFLP markers (71\%). These findings are consistent with other studies comparing the level of polymorphism detected with SSR and AFLP markers [11, 16], and can be explained by the fact that SSR markers detect multiple alleles at a given locus, usually pre-selected for its high variability, whereas AFLP assays mainly detect single alleles at multiple loci randomly distributed in the genome.

A Mantel test of the two genetic distance matrices derived from SSR and AFLP data, respectively, yielded a correlation coefficient of only $0.12(P=0.89)$, which indicates that the two marker systems have not produced concordant results. Genetic distances are often closely correlated when different multi-locus marker methods (like AFLP, RAPD and ISSR) are compared [34]. By contrast, comparison of a multi-locus method with SSR markers can result in poor correlation, especially when number of SSR bands evaluated is too low. The present study is a first report to assess genetic variation among and within populations of $N$. ditissima in European countries using both SSR and AFLP markers.

\section{Genetic variation between and within orchards}

Analysis of molecular variation (AMOVA) among 44 AFLP-screened isolates, obtained from eight different orchards, revealed only $11 \%$ genetic differentiation among

Table 2 Number of alleles (NA), Nei's gene diversity $(\mathrm{H})$ and Shannon's information index (I) for seven SSR primer pairs used to study variation among 28 isolates of $\mathrm{N}$. ditissima

\begin{tabular}{llll}
\hline Primer name & NA & $H$ & I \\
\hline NdCAA3 & 7 & 0.24 & 0.38 \\
NdCAA11 & 7 & 0.17 & 0.30 \\
NdGGT2 & 5 & 0.22 & 0.36 \\
NdGGT3 & 3 & 0.35 & 0.51 \\
NdGGT23 & 2 & 0.13 & 0.26 \\
NdGGT39 & 5 & 0.69 & 0.15 \\
NdGGT44 & 2 & 0.14 & 0.26 \\
Total & 31 & & \\
Average & 4 & 0.28 & 0.32 \\
\hline
\end{tabular}


Table 3 Number of loci (NL), number of polymorphic loci (NPL), percentage of polymorphic loci (PPL), Nei's gene diversity $(\mathrm{H})$ and Shannon's information index (I) for 11 AFLP primer combinations used to study variation among 44 isolates of $N$. ditissima

\begin{tabular}{llllll}
\hline Primer combinations & $\mathrm{NL}$ & $\mathrm{NPL}$ & $\mathrm{PPL}$ & $\mathrm{H}$ & $\mathrm{I}$ \\
\hline $\mathrm{E}+\mathrm{AA} / \mathrm{M}+\mathrm{CA}$ & 40 & 35 & 87 & 0.20 & 0.33 \\
E+A/M+CT & 56 & 31 & 55 & 0.10 & 0.17 \\
E+T/M+CT & 58 & 37 & 64 & 0.14 & 0.22 \\
E+AC/M+CT & 29 & 18 & 62 & 0.18 & 0.28 \\
E+AC/M+CA & 25 & 18 & 72 & 0.14 & 0.23 \\
E+AG/M+CT & 33 & 25 & 76 & 0.17 & 0.26 \\
E+AT/M+CT & 38 & 27 & 71 & 0.13 & 0.21 \\
E+AA/M+CT & 42 & 25 & 59 & 0.09 & 0.16 \\
E+AG/M+CG & 22 & 16 & 73 & 0.17 & 0.27 \\
E+AC/M+CC & 27 & 26 & 96 & 0.21 & 0.34 \\
E+AC/M+CG & 21 & 14 & 67 & 0.13 & 0.22 \\
Total & 391 & 272 & & & \\
Average & 35 & 25 & 71 & 0.15 & 0.24 \\
\hline
\end{tabular}

orchards, while the remaining $89 \%$ of the variation resided within orchards. As expected, number of polymorphic bands detected in each orchard was closely associated with the number of isolates investigated. The highest number of polymorphic AFLP bands was observed in the orchard at Balsgård (201 bands among 26 isolates from 10 trees) followed by Gembloux (102 bands among four isolates) while Jönköping had the lowest number (42 bands among 2 isolates). The highest number of SSR bands was also found at Balsgård (14) and
Gembloux (12) while the lowest number (3) was identified in Stockholm (two isolates sampled) (Table 4).

When calculated at the species level, Nei's gene diversity and Shannon's information index were 0.14 and 0.23 based on AFLP data (44 isolates in total), respectively, and 0.19 and 0.32 based on SSR data (28 isolates), respectively (Table 4). At the population (i.e. orchard) level, Balsgård and Gembloux had the highest values for Nei's gene diversity and Shannon's information index for both AFLP and SSR markers. When based on AFLP data, Nei's gene diversity and Shannon's information index was 0.13 and 0.21, respectively, at Balsgård, and 0.05 and 0.07, respectively, at Jönköping where the lowest values were encountered. For SSR marker data, Gembloux and Balsgård had a Nei's gene diversity of 0.15 and 0.14 , respectively, and a Shannon's information index of 0.22 for both orchards. The lowest values were instead encountered at Stockholm ( 0.05 and 0.07 , respectively). It should, however, be noted that all the estimates of intra-population variation are based on very few isolates and are therefore unlikely to be representative of the species at large. In the previous study where these SSR primer pairs were developed and evaluated on a single $N$. ditissima population sampled on black birch, Nei's gene diversity was considerably higher (0.48) [19]. The latter population was, however, also much larger (38 isolates) which may explain the difference in diversity.

Only $11 \%$ of the variation resided between populations in the present study as assessed by the AFLP markers. Rather low values for population differentiation have been reported also in other studies on molecular variation in

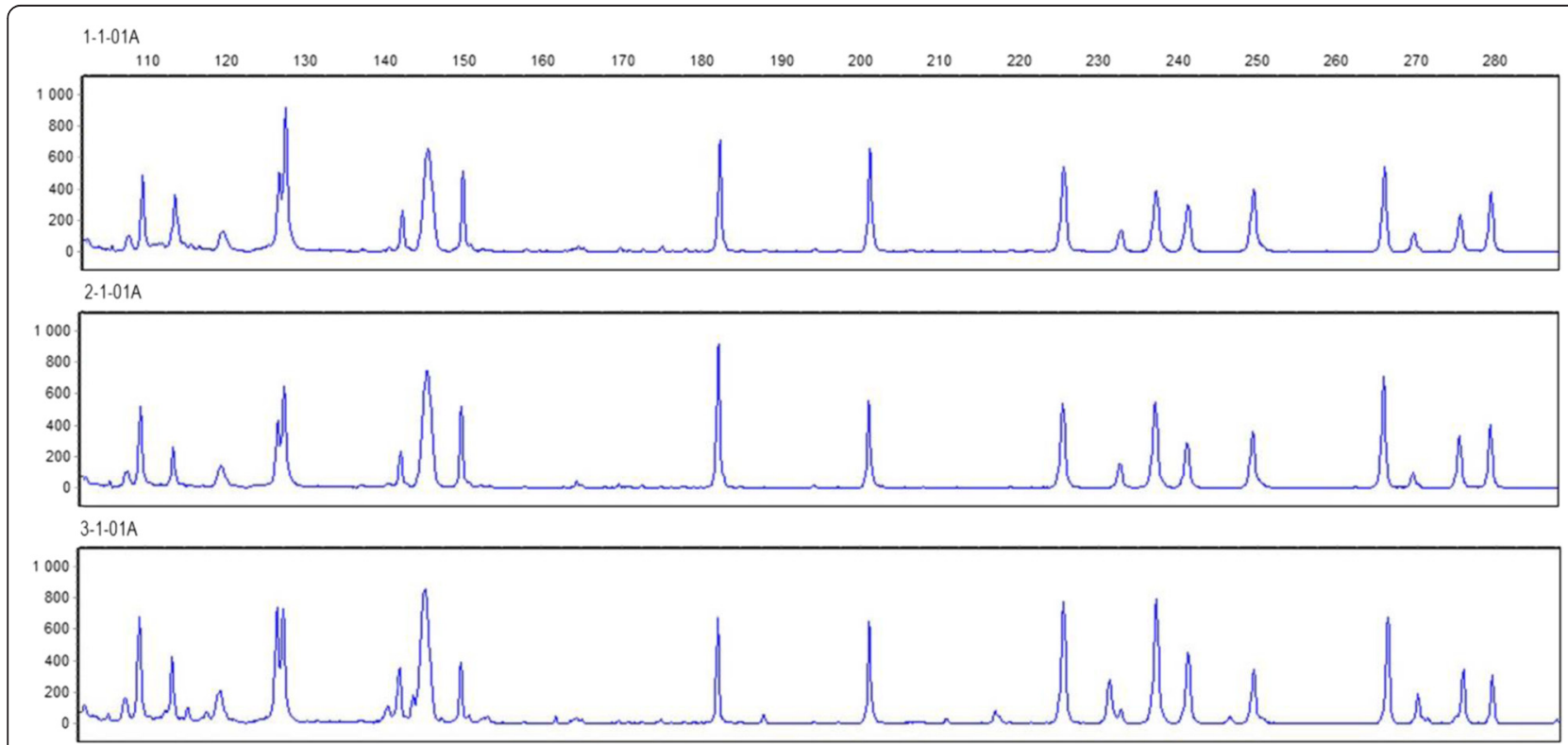

Fig. 2 Electropherograms generated from 3 runs on an $A B \mid 3130 x$ of the same sample that obtained with the primer combination $E+T / M+C T$. They indicated high reproducibility of AFLP marker 
Table 4 Number of polymorphic loci (NPL) and percentage of polymorphic loci (PPL) for AFLP, number of polymorphic alleles (NPA) and percentage of polymorphic alleles (PPA) for SSR, Nei's gene diversity $(\mathrm{H})$ and Shannon's information index (I) for populations of Neonectria ditissima from different orchards based on AFLP with 44 isolates and SSR markers with 28 isolates

\begin{tabular}{|c|c|c|c|c|c|}
\hline & & NPL & PPL & $\mathrm{H}$ & 1 \\
\hline AFLP Marl & & & & & \\
\hline Genetic di & ty of the eight popula & & & & \\
\hline Orchards & Balsgård, Sweden & 201 & 51 & 0.13 & 0.21 \\
\hline & Bjärred, Sweden & 88 & 22 & 0.10 & 0.14 \\
\hline & Kivik, Sweden & 64 & 16 & 0.08 & 0.11 \\
\hline & Julita, Sweden & 60 & 15 & 0.07 & 0.10 \\
\hline & Jonstorp, Sweden & 80 & 20 & 0.09 & 0.13 \\
\hline & Jönköping, Sweden & 42 & 11 & 0.05 & 0.07 \\
\hline & Stockholm, Sweden & 67 & 17 & 0.08 & 0.12 \\
\hline & Gembloux, Belgium & 102 & 26 & 0.10 & 0.15 \\
\hline & Mean & 88 & 22.2 & 0.09 & 0.13 \\
\hline Genetic di & ty among 44 isolates & & & & \\
\hline 44 isolate & & 272 & 69 & 0.14 & 0.23 \\
\hline & & NPA & PPA & $\mathrm{H}$ & I \\
\hline SSR Marke & & & & & \\
\hline Genetic di & ty of the eight popula & & & & \\
\hline Orchards & Balsgård, Sweden & 14 & 45 & 0.14 & 0.22 \\
\hline & Bjärred, Sweden & 9 & 29 & 0.13 & 0.18 \\
\hline & Kivik, Sweden & 7 & 23 & 0.11 & 0.16 \\
\hline & Julita, Sweden & 5 & 16 & 0.08 & 0.11 \\
\hline & Jonstorp, Sweden & 6 & 19 & 0.09 & 0.12 \\
\hline & Jönköping, Sweden & 6 & 19 & 0.10 & 0.13 \\
\hline & Stockholm, Sweden & 3 & 10 & 0.05 & 0.07 \\
\hline & Gembloux, Belgium & 12 & 39 & 0.15 & 0.22 \\
\hline & Mean & 7.7 & 25 & 0.11 & 0.15 \\
\hline Genetic di & ty among 28 isolates & & & & \\
\hline 28 isolates & & 31 & 100 & 0.19 & 0.32 \\
\hline
\end{tabular}

fungi. AFLP-based studies have thus shown that $7 \%$ of the total genetic variability occurred between populations of Fusarium pseudograminearum [12] and $14 \%$ between populations of Phytophthora colocasiae [24] while $11 \%$ of SNP-based variability occurred between populations of Ustilaginoidea virens [29]. Low genetic differentiation is often hypothesized to result from high levels of gene flow thus preventing geographic subdivision [15]. Since the apple canker fungus occurs on cultivated crops, gene flow is probably augmented by movement of plant material from one area to another, e.g. from commercial plant nurseries in Belgium to orchards in Sweden as well as between orchards. Another possible explanation for the lack of strong inter-populational differentiation among isolates is a high degree of spontaneous mutations. A large number of spores is produced by the fungus in a short period of time, and the diversity could therefore be influenced by mutations [3].

\section{Mating system of $N$. ditissima}

In order to determine the most likely mode of reproductive system in $N$. ditissima and to quantify genetic variation among isolates at different levels of genetic relatedness, single-ascospore isolates derived from the same or from different perithecia on a single tree, were analyzed with both AFLP and SSR markers (Table 1). A set of 45 singleascospore isolates representing five different trees from different orchards (nine single-ascospore isolates from three perithecia on each tree) was analyzed with SSR, yielding identical profiles when isolates from the same tree were compared (data not shown).

Subsequently, a set of 19 single-ascospore isolates sampled in the orchard at Balsgård (five from three perithecia on a 'Red Delicious' tree, eight from three perithecia on a 'Holsteiner Cox' tree and six from two perithecia on a 'Gravensteiner' tree) was analyzed with AFLP. Average pairwise similarity was analyzed at three levels; 1 ) among different single-ascospore isolates derived from the same perithecium, b) among single-ascospore isolates derived from different perithecia on the same tree, and c) among single-ascospore isolates derived from different trees (Table 5). For level 1, pairwise comparisons of isolates using Jaccard's similarity coefficient ranged from 0.73 to 1.00 with a mean of 0.85 . For level 2 , Jaccard's similarity coefficients ranged from 0.60 to 0.87 with a mean of 0.76 , suggesting that genetic relatedness is lower among isolates from different perithecia compared to isolates originating from the same perithecium. Finally, for level 3, Jaccard's similarity coefficients calculated on comparisons between isolates from different trees in the same orchard ranged from 0.44 to 0.70 , with a mean of 0.56 .

Since fingerprint profiles evidently vary amongst sibling progeny, outcrossing seems to occur in $N$. ditissima. Still, occasional selfing cannot be ruled out since two of the isolates from perithecium number 3 on 'Red Delicious' were highly identical and the third differed only to a very minor extent from the other two (Jaccard's similarity coefficient $=0.94$ ).

Both haploid selfing [9] and outcrossing [14] has previously been reported in $N$. ditissima according to morphological characterization of ascospores. In general, sexual recombination has the potential to increase genotype diversity since novel recombinants are created, and genetic recombination through sexual crosses have been shown to be correlated with genetic diversity [29]. In the current study, genetic variation among single-ascospore isolates from different perithecia was higher than singleascospore isolates from the same perithecium, which 
Table 5 AFLP-based variation estimated with Jaccard's similarity coefficients among single-ascospore isolates originating from within the same or from different perithecia of $N$. ditissima

\begin{tabular}{|c|c|c|c|c|c|}
\hline \multicolumn{2}{|c|}{ Within the same perithecium } & \multicolumn{2}{|c|}{ Between different perithecia on the same tree } & \multicolumn{2}{|c|}{ Between different perithecia on different trees in the same orchard } \\
\hline RP3: & & RP1 $\times R P 2 \times R P 3:$ & & RPXGP: & \\
\hline Mean & 0.96 & Mean & 0.75 & Mean & 0.56 \\
\hline Max & 1 & Max & 0.85 & Max & 0.68 \\
\hline Min & 0.94 & Min & 0.60 & Min & 0.45 \\
\hline GP1: & & GP1×GP2: & & RPXHP: & \\
\hline Mean & 0.76 & Mean & 0.77 & Mean & 0.56 \\
\hline Max & 0.84 & Max & 0.87 & Max & 0.69 \\
\hline Min & 0.73 & Min & 0.61 & Min & 0.44 \\
\hline GP2 : & & HP1×HP2XHP3: & & GPXHP: & \\
\hline Mean & 0.85 & Mean & 0.76 & Mean & 0.58 \\
\hline Max & 0.90 & Max & 0.84 & Max & 0.70 \\
\hline Min & 0.80 & Min & 0.63 & Min & 0.45 \\
\hline HP1: & & Mean & 0.76 & Mean & 0.56 \\
\hline Mean & 0.86 & & & & \\
\hline Max & 0.90 & & & & \\
\hline Min & 0.84 & & & & \\
\hline \multicolumn{6}{|l|}{ HP2: } \\
\hline Mean & 0.86 & & & & \\
\hline Max & 0.90 & & & & \\
\hline Min & 0.83 & & & & \\
\hline Mean & 0.85 & & & & \\
\hline
\end{tabular}

R, G and H are different apple cultivars; R: 'Red Delicious', G: 'Gravensteiner', H: 'Holsteiner Cox', P1-3: different perithecia of each cultivar Bold data indicate the total average pairwise similarity at three levels

suggests that each tree has been colonized by several genetically different spores. Moreover, perithecia on different trees in the same orchard produced even more genetically different spores. Obviously, colonization of the fungus within an orchard involves several different, sexually derived ascospores. Management of diseases caused by sexually reproducing pathogens becomes more difficult due to the constant appearance of new genotypes, which increase the variation of features like fungicide resistance. In addition, $N$. ditissima produces asexual spores during a large part of the year. Pathogens that reproduce both sexually and asexually are especially difficult to control, since aggressive isolates selected after sexual reproduction can increase asexually and then disperse widely within a short time-span [22].

\section{Phenetic analyses}

Both SSR and AFLP data were used for estimating the distribution of genetic variation among and within orchards. An SSR-based principal coordinates analysis (PCoA) of similarities among 28 isolates did not produce any distinct groupings of isolates from different trees growing in the same orchard (Fig. 3). Neither was an impact from geographical distances among the eight sampled orchards detected. In this analysis, the first two dimensions (dim-1 and dim-2) explained 65.7 and $6.9 \%$ of the genetic variation, respectively. A PCoA based on AFLP data for the same 28 isolates similarly failed to produce any groupings of the material (Fig. 4), and 85.7 and $1.4 \%$ of the genetic variation were explained by dim-1 and dim-2, respectively. Obviously, isolates from the same or geographically close orchards did not group together in the PCoA analysis with either marker type.

When the AFLP data for single-ascospore isolates arising from different perithecia on three trees at Balsgård was subjected to a cluster analysis, three distinct groups were formed, each with isolates originating from the same tree, namely groups A (isolates from a 'Red Delicious' tree at Balsgård), B (isolates from a 'Gravensteiner' tree at Balsgård) and C (isolates from a 'Holsteiner Cox' tree at Balsgård) (Fig. 5). The cophenetic correlation coefficient was 0.94 , indicating that the dendrogram was a good fit of the original data [18].

The identity of the cultivar from which the perithecia were sampled, did not appear to influence distribution of genetic variation of the resulting isolates. A possible explanation might be that there is random mating in the $N$. ditissima population. By contrast, significant differences 


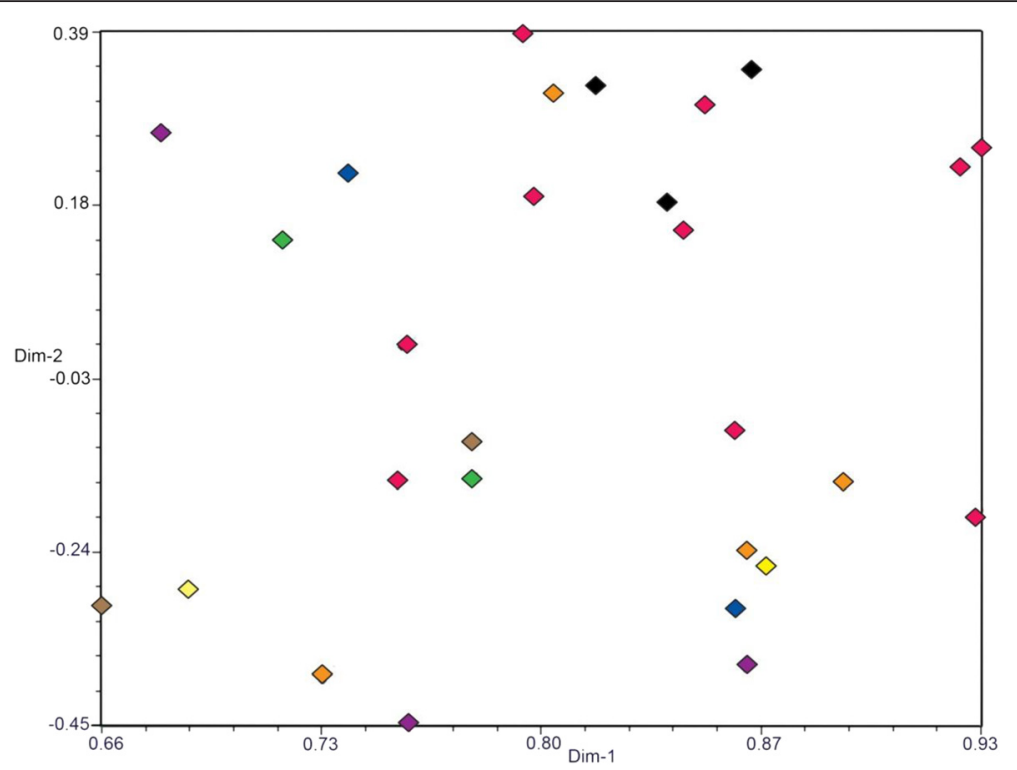

Fig. 3 Principal coordinate analysis (PCOA) based on SSR data with 28 isolates. (black diamond): Jonstorp, (blue diamond): Julita, (green diamond): Jönköping, (yellow diamond): Kivik, (pink diamond): Balsgård, (purple diamond): Bjärred, (orange diamond): Gembloux, (brown diamond): Stockholm

among fungal populations of Venturia inaequalis, the causal agent of apple scab, collected from different apple cultivars indicated non-random mating [35].

Pathogenicity traits of fungal pathogens can be augmented by so-called pestification processes, which affect mainly growth and dispersal. Previous studies have thus shown that apple domestication has had a considerable impact on the modification of pathogenicity of $V$. inaequalis [31] and that the aggressiveness of this fungus has increased during the domestication process [8]. The extent to which these findings, obtained for the hemibiotrophic, ephemeral (trees are re-colonized each year) and multi-race fungus Venturia, can be expected also in a necrotrophic and polyphagous fungus like Neonectria is not known. Evolution of fitness-related traits is extremely dependent on the different life histories such as predominance of sexual over asexual reproduction [26].

Information on the distribution of genetic diversity of fungal populations may indicate how spread of the pathogen is accomplished, and this can be used to predict how

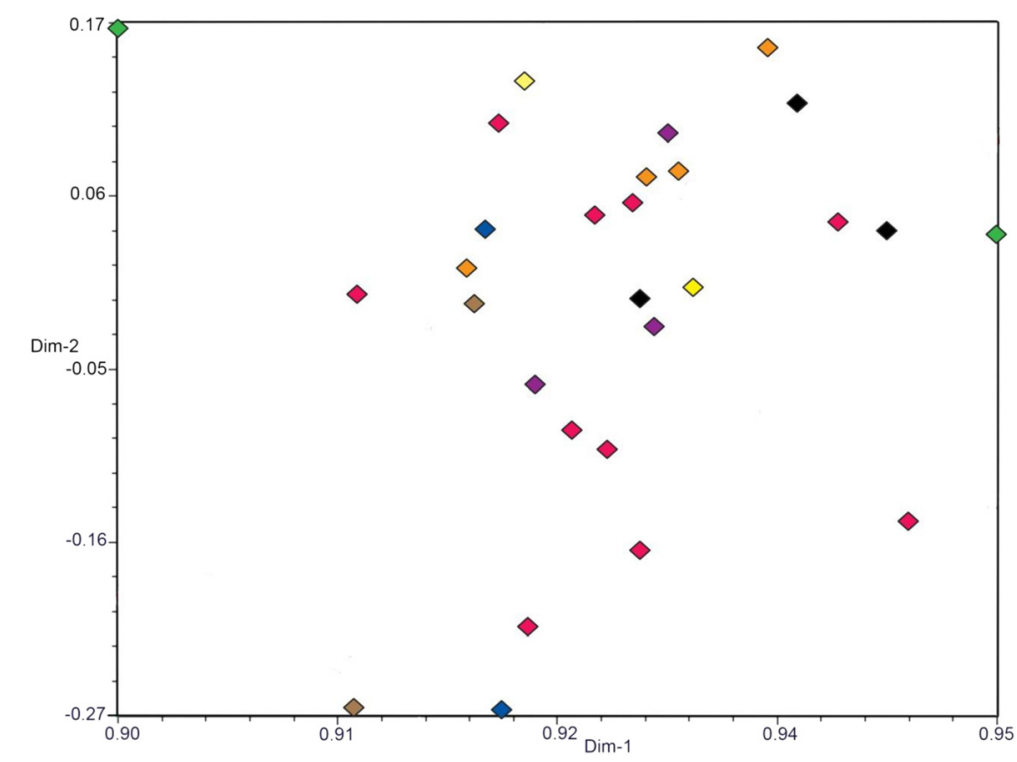

Fig. 4 Principal coordinate analysis (PCOA) based on AFLP data with 28 isolates. (black diamond): Jonstorp, (blue diamond): Julita, (green diamond): Jönköping, (yellow diamond): Kivik, (pink diamond): Balsgård, (purple diamond): Bjärred, (orange diamond): Gembloux, (brown diamond): Stockholm 


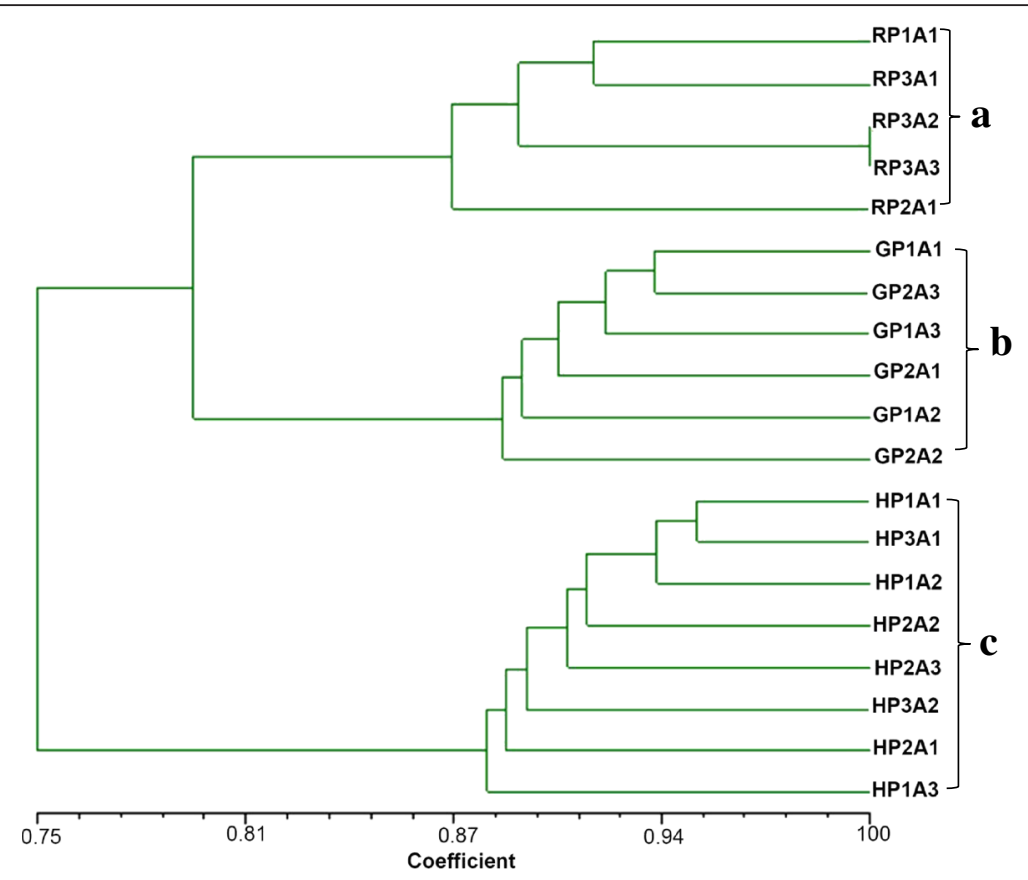

Fig. 5 Dendrogram obtained with UPGMA based on AFLP data of single-ascospore isolates arising from different perithecia of $N$. ditissima. R: Red Delicious, G: Gravensteiner, H: Holsteiner Cox, P1-3: different perithecia, A1-3: different single-ascospores. Vertical bars show all isolates arising from different perithecia of a 'Gravensteiner', b 'Red Delicious' and c 'Holsteiner Cox'

long a control measure is likely to be effective [23]. A previous study has shown that fungal populations with regular sexual reproduction recombine their genes into new combinations while populations with asexual reproduction have a more limited number of different gene combinations [23]. In the present study, sexually produced spores were used to evaluate genetic variation. The intra-population variation detected is probably largely due to sexual recombination. Gene flow, mutation and selection are hypothesized as the most important mechanisms of variation in $N$. ditissima populations. Strategies for improved control should therefore include restricted movement of infected plant material, or contaminated equipment.

\section{Conclusions}

To the best of our knowledge, studies of genetic variation in $N$. ditissima on Malus domestica have not been reported before in Sweden or Belgium. In this study, genetic diversity of $N$. ditissima was estimated at an inter-population level using isolates from different apple orchards in Sweden and from one orchard in Belgium since trees grown in commercial Swedish orchards are often imported from Belgium. In addition, the mating system of the pathogen was investigated at an intra-population level by comparing sibling single-ascospore progeny either from a single perithecium or from different perithecia of the same tree. First, Simple Sequence Repeat (SSR) was used, which is a singlelocus method with co-dominantly inherited bands. Each primer pair produces one band in each isolate (the studied species is haploid). These bands can have different size in different isolates. Since total number of polymorphic SSR alleles turned out to be rather low, the Amplified Fragment Length Polymorphism (AFLP) method was applied to complement the SSR data. AFLP is a multi-locus method with dominantly inherited bands, with each primer pair producing multiple bands in each isolate. When several isolates are compared, individual AFLP bands are either present or absent [34].

\section{Abbreviations}

AFLP, amplified fragment length polymorphism; AMOVA, analysis of molecular variance; EF1-a, elongation factor 1-alpha; ISSR, application of inter simple sequence repeat; $\mathrm{PCOA}$, principal coordinates analysis; RAPD, random amplified polymorphic DNA; RPB2, RNA polymerase II second largest subunit; SSR, simple sequence repeat; UPGMA, unweighted pairwise group method with arithmetic mean

\section{Acknowledgements}

We are grateful to Eva Eneblad, Dr. Marc Lateur and Björn Kalin for providing fungal material.

\section{Funding}

Financial support was obtained from the Nordic Ministries of Food and Agriculture through the Nordic collaboration on Public-Private Partnership for pre-breeding, PPP, administered by NordGen.

\section{Authors' contributions}

MG performed the experiments, analyzed the data and wrote the manuscript. $\mathrm{HN}$ designed the experiments and HN and LG-G participated in the sampling of the isolates. EL helped with the isolation of Neonectria ditissima. EL, HN and LG-G helped to develop the concept of the paper and assisted in manuscript writing. All authors read and approved the final manuscript. 


\section{Competing interests}

The authors declare that they have no competing interests.

\section{Author details}

'Department of Plant Breeding, Swedish University of Agricultural Sciences, Box 101, 23053 Alnarp, Sweden. 'Department of Plant Protection Biology, Swedish University of Agricultural Sciences, Box 10223053 Alnarp, Sweden. ${ }^{3}$ Department of Plant Breeding, Swedish University of Agricultural Sciences, Balsgård, Fjälkestadsvägen 459, 29194 Kristianstad, Sweden.

\section{Received: 27 February 2016 Accepted: 15 June 2016}

\section{Published online: 01 July 2016}

\section{References}

1. Bernier L, Hubbes M. Mutations in Ophiostoma ulmi induced by $\mathrm{N}$-methylN'-nitro-N-nitroso-guanidine. Can J Bot. 1990;68:225-31.

2. Billiard S, López-Villavicencio M, Hood M, Giraud T. Sex, outcrossing and mating types: unsolved questions in fungi and beyond. J Evol Biol. 2012;25(6):1020-38.

3. Carlile MJ, Watkinson SC, Gooday GW. The Fungi. Houston: Gulf Professional Publishing; 2001

4. Castlebury LA, Rossman AY, Hyten AS. Phylogenetic relationships of Neonectria/Cylindrocarpon on Fagus in North America. Can J Bot. 2006; 84:1417-33

5. Chatelet DS, Wistrom CM, Purcell AH, Rost TL, Matthews MA. Xylem structure of four grape varieties and 12 alternative hosts to the xylemlimited bacterium Xylella fastidious. Ann Bot-London. 2011;108:73-85.

6. $\mathrm{CPCl}$. Crop Protection Compendium on Internet. Wallingford: $\mathrm{CAB}$ International; 2014. www.cabi.org/cpc

7. Czembor PC, Arseniuk E. Segregation and recombination of PCR based markers in sexual progeny of Phaeosphaeria species. Mycol Res. 2000;104:919-26.

8. De Gracia M, Cascales M, Expert P, Bellanger M-N, Le Cam B, Lemaire C How did host domestication modify life history traits of its pathogens? PLoS One. 2015;10:e0122909.

9. El-Gholl N, Barnard E, Schroeder R. Homothallism in Nectria galligena. Can J Bot. 1986;64:902-3.

10. Excoffier L, Laval G, Schneider S. Arlequin (version 3.0): an integrated software package for population genetics data analysis. Evol Bioinform Online. 2005;1:47.

11. Fofana IJ, Silue S, Diarrassouba N, Kadio AA, Sangare A. Comparative analyses of amplified fragment length polymorphism (AFLP) and simple sequence repeat (SSR) in genetic diversity of Teak (Tectona grandis Lf). Int J Adv Agric Res. 2013;1:114-23.

12. Gargouri S, Hamza S, Hajlaoui M. AFLP analysis of the genetic variability and population structure of the wheat crown rot fungus Fusarium pseudograminearum in Tunisia. Tunis J Plant Prot. 2006;1:93-104.

13. Ghasemkhani M, Holefors A, Marttila S, Dalman K, Zborowska A, Rur M, Rees-George J, Nybom H, Everett KR, Scheper RWA, Garkava-Gustavsson L. Real-time PCR for detection and quantification, and histological characterization of Neonectria ditissima in apple trees. Trees. 2016. doi:10. 1007/s00468-015-1350-9.

14. Krüger J. Zur Genetik von Nectria galligena Bres. J Phytopathol. 1974;79:320-42.

15. Lenormand T. Gene flow and the limits to natural selection. Trends Ecol Evol. 2002;17:183-9.

16. Li L, Wanapu C, Huang X, Huang T, Li Q, Peng Y, Huang G. Comparison of AFLP and SSR for genetic diversity analysis of Brassica napus hybrids. J Agric Sci. 2011:3:101-10.

17. Mahoney EM, Milgroom MG, Sinclair WA. Origin, genetic diversity and population structure of Nectria coccinea var. faginata in North America. Mycologia. 1999;91:583-92.

18. Mantel N. The detection of disease clustering and a generalized regression approach. Cancer Res. 1967;27:209-20.

19. Marra RE, Corwin JA. Isolation and characterization of codominant markers for the perennial canker fungal pathogen Neonectria ditissima. Mol Ecol Resour. 2009;9:906-9.

20. McCracken AR, Berrie A, Barbara DJ, Locke T, Cooke LR, Phelps K, Swinburne TR, Brown AE, Ellerker B, Langrell SRH. Relative significance of nursery infections and orchard inoculum in the development and spread of apple canker (Nectria galligena) in young orchards. Plant Pathol. 2003;52:553-66.
21. McDonald BA. The population genetics of fungi: tools and techniques. Phytopathology. 1997:87:448-53.

22. McDonald BA, Linde C. Pathogen population genetics, evolutionary potential, and durable resistance. Annu Rev Phytopathol. 2002:40:349-79.

23. McDonald BA, McDermott JM. Population Genetics of Plant Pathogenic Fungi. Bioscience. 1993:43:311-9.

24. Nath VS, Senthil M, Hegde VM, Jeeva ML, Misra RS, Veena SS, Raj M. Genetic diversity of Phytophthora colocasiae isolates in India based on AFLP analysis. 3 Biotech. 2013:3:297-305.

25. Plante F, Hamelin RC, Bernier L. A comparative study of genetic diversity of populations of Nectria galligena and N. coccinea var. faginata in North America. Mycol Res. 2002;106:183-93.

26. Pringle A, Taylor JW. The fitness of filamentous fungi. Trends Microbiol. 2002;10:474-81.

27. Seymour FA, Crittenden PD, Dickinson MJ, Paoletti M, Montiel D, Cho L, Dyer PS. Breeding systems in the lichen-forming fungal genus Cladonia. Fungal Genet Biol. 2005;42:554-63.

28. Shaner G, Finney RE. Effect of nitrogen-fertilization on expression of slowmildewing resistance in Knox wheat. Phytopathology. 1977;67:1051-6.

29. Sun X, Kang S, Zhang Y, Tan X, Yu Y, He H, Zhang X, Liu Y, Wang S, Sun W. Genetic diversity and population structure of rice pathogen Ustilaginoidea virens in China. PLoS One. 2013:8:e76879.

30. Tamura K, Dudley J, Nei M, Kumar S. MEGA4: molecular evolutionary genetics analysis (MEGA) software version 4.0. Mol Biol Evol. 2007:24:1596-9.

31. Van Lê A, Gladieux P, Lemaire C, Cornille A, Giraud T, Durel CE, Caffier V, Le Cam B.Evolution of pathogenicity traits in the apple scab fungal pathogen in response to the domestication of its host. Evol Appl. 2012;5:694-704.

32. Walser J, Gugerli F, Holderegger R, Kuonen D, Scheidegger C. Recombination and clonal propagation in different populations of the lichen Lobaria pulmonaria. Heredity. 2004;93:322-9.

33. Weber RWS. Biology and control of the apple canker fungus Neonectria ditissima (syn. N. galligena) from a Northwestern European perspective. Erwerbs-Obstbau. 2014;56:95-107.

34. Weising $K$, Nybom H, Pfenninger M, Wolff $K$, Kahl G. DNA fingerprinting in plants: principles, methods, and applications. Boca Raton: CRC press; 2005

35. Xu X, Harvey N, Roberts A, Barbara D. Population variation of apple scab (Venturia inaequalis) within mixed orchards in the UK. Eur J Plant Pathol. 2013;135:97-104.

36. Yeh FC, Yang R, Boyle TB, Ye Z, Mao JX. POPGENE, the user-friendly shareware for population genetic analysis. Canada: Molecular Biology and Biotechnology Centre, University of Alberta; 1997.

\section{Submit your next manuscript to BioMed Central and we will help you at every step:}

- We accept pre-submission inquiries

- Our selector tool helps you to find the most relevant journal

- We provide round the clock customer support

- Convenient online submission

- Thorough peer review

- Inclusion in PubMed and all major indexing services

- Maximum visibility for your research

Submit your manuscript at www.biomedcentral.com/submit
) Biomed Central 